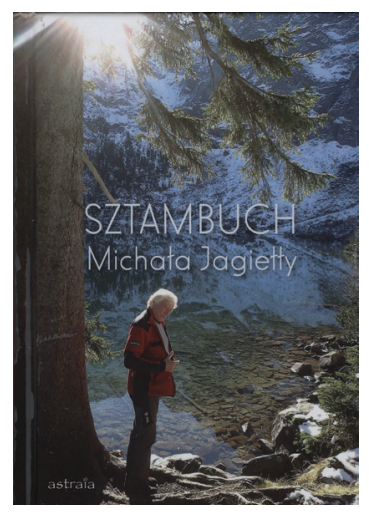

\title{
W sztambuchu Michała Jagiełły
}

DOI: $10.19195 / 2084-4107.11 .38$

[rec.:] Sztambuch Michała Jagietly, wydawnictwo Astraia, Kraków 2017, ss. 246.

In Michał Jagiełto's album

Słowa-klucze: Michał Jagiełło, Tatry, sztambuch, wspomnienia

Keywords: Michał Jagiełło, Tatras, album, memoirs

Z pojęciem sztambucha łączy się przede wszystkim sytuacja pożegnania. Szesnasto- i siedemnastowieczne sztambuchy uniwersyteckiej młodzieży służyły wpisywaniu się na pamiątkę przy okazji zakończenia edukacji, które wówczas oznaczało rozstanie - czasem na zawsze. Przywołanie tej przebrzmiałej już formy w tytule niezwykłej książki wspomnieniowej jest interesującym zabiegiem, zdradzającym cel autorów tekstów w tej publikacji zawartych — celem tym jest właśnie ostatnie pożegnanie bliskiego im człowieka.

Zbigniew Ładygin w swoim wspomnieniu o Michale Jagielle pisze: „zauważyłem pewną prawidłowość: ilekroć wspominamy kogoś, kto odszedł, mówimy o sobie" (s. 90).

Trudno się nie zgodzić z tym spostrzeżeniem w kontekście zbioru mieszczącego 47 różnej długości wspomnień, notatek, urywków dotyczących wybitnego taternika, TOPR-owca, polonisty, poety i polityka, zmarłego 1 lutego $2016 \mathrm{r}$. Michała Jagiełły. Owe wspomnienia o przyjacielu, artyście, autorytecie i współpracowniku w dużej mierze mają charakter bardzo osobisty. Wśród ich autorów są przedstawiciele nauki, kultury oraz ludzie gór (taternicy). 
Ogromną siłą zbioru jest jego różnorodność. Niektóre wspomnienia są bowiem swoistymi obrazkami, krótkimi, jedno- lub dwustronicowymi fragmentami dotyczącymi jakiejś konkretnej sytuacji bądź wybranego, szczególnego spotkania autora wspomnienia z Michałem Jagiełłą, które z jakiegoś ważnego powodu pozostało zapamiętane. Wśród nich znajdują się np. literackie miniatury kompozytora Edwarda Dębickiego oraz fotografa Marka Grzesiaka. Dębicki wspomina poznanie Jagiełły jako wiceministra kultury: urzędnika, z którym rozmowa była „przyjazna, serdeczna i pełna troski” (s. 28). Grzesiak zaś docenia, że mimo objęcia przez Jagiełłę stanowiska wiceministra w roku 1989 nie zrezygnował on z fizycznej pracy wysokościowej, do której się zobowiązał.

Inne teksty są rozbudowanymi szkicami: jak wywód Teresy Jabłońskiej dotyczący w przeważającej mierze związków Jagiełły z Muzeum Tatrzańskim, w którym autor słynnego Wołania w górach pracował przez dwa lata i gdzie później odbywały się promocje jego książek:

Na wieczorach autorskich Michała „salon literacki” w Kolibie pękał w szwach od publiczności. Opowiadał ciekawie i szybko nawiązywał dobry kontakt ze słuchaczami. Czuło się, że Tatry nie tylko znakomicie zna, ale też kocha — z góralska mówił, że został „sieknięty” przez góry. Osobisty i silnie emocjonalny stosunek do gór oddają jego utwory literackie - opowiadania i wiersze (s. 47).

Wspomnień, w których dominuje aspekt biograficzny, jest w tomie więcej. Prezentują one koleje losu Jagiełły, wymieniają wykonywane przez niego zawody, charakteryzują jego dorobek pisarski i publicystyczny. Taki charakter mają wspomnienia Oskara Stanisława Czarnika, Macieja Krupy czy Mieczysława Orskiego.

Z kolei Monika Krajewska odnosi się do tatrzańskiej poezji Michała Jagiełły, pisząc: „W wierszach Michała Tatry to nie góry przez wielkie G, abstrakcyjne i dalekie. Są prawdziwe, nie dlatego — nie tylko dlatego — że autor delektuje się nazwami turni i przełęczy, wymawianymi pieszczotliwie jak imiona bliskich. Są prawdziwe przez swoją tatrzańskość, widzianą w zbliżeniu, w ciasnym kadrze" (s. 73). Ta konkluzja w jakimś stopniu koresponduje z koncepcją Sztambucha, który ze względu na szczerość i autentyczność wypowiedzi autorów zamieszczonych w nim wspomnień pozwala na przybliżenie postaci Jagiełły, by powtórzyć za Moniką Krajewską: „w zbliżeniu, w ciasnym kadrze” (s. 73).

Poszczególne teksty dotykają nie tylko rozmaitych aspektów jego życiorysu — działalności politycznej, pisarskiej czy związków z Zakopanem - ale ukazują także różne cechy jego charakteru, znamiona tożsamości, a także specyfikę przeszłości, która go ukształtowała: Jagiełło jawi się zatem czytelnikom także jako „chłopski syn” (Włodzimierz Kalicki, Między górami a bibliotekami). Jest to tym ważniejsze, że Jagiełło przez całe życie owo chłopskie pochodzenie mocno eksponował i nie jest przesadą stwierdzenie, że było ono przedmiotem jego osobistej dumy i fundamentem wyraźnej tożsamości. W omawianych tu wspomnieniach 
wielokrotnie akcentuje się również bardzo charakterystyczną dla osobowości Jagiełły serdeczność, ciepło i oddanie drugiemu człowiekowi.

Sztambuch zawiera także wypowiedzi bardzo osobiste, przywołujące fragmenty rozmów z Jagiełłą bądź relacjonujące przebieg ostatniego z nim spotkania. Wiesław A. Wójcik wspomina np. ich ostatni wspólny obiad w Warszawie i późniejszą telefoniczną rozmowę:

Po raz ostatni widziałem Michała w sobotę 21 listopada 2015 roku w Warszawie. Było to na następny dzień po obronie mego doktoratu na Uniwersytecie Wrocławskim. Zadzwonił do mnie na komórkę, chciał się bowiem ze mną spotkać. [...] Kiedy dochodziłem do umówionego miejsca, Michał już tam był i, zoczywszy mnie, już z daleka wołał: — Witam doktora! Był pierwszym spoza grona świadków tej obrony, który składał mi gratulacje. [...] Jakoś w ostatnią styczniową środę lub we czwartek wyrwał mnie z półsnu telefon. To dzwonił Michał, z prośbą o podanie adresu bibliograficznego jednej z moich publikacji poświęconej dziejom tatrzańskiej literatury przewodnikowej [...]. Ta krótka rozmowa odbyła się — jak wspomniałem — gdzieś we środę lub czwartek, a już w najbliższy poniedziałek, w godzinach późnoporannych zatelefonował do mnie Zbyszek Ładygin z wręcz nieprawdopodobną wiadomością, że Michał nie żyje i że zmarł niebawem po przyjeździe pod Tatry.

Gdyby wyodrębnić zagadnienia, które najczęściej pojawiają się w kilkudziesięciu obrazach przywołujących osobę Jagiełły, byłyby to: miłość do Tatr i Zakopanego; dorobek pisarski, zarówno powieściowy, poetycki, jak i naukowy; a także, co może zaskakujące, działalność w PZPR. Autorzy — przecież przyjaciele Jagiełły, jego bliscy, współpracownicy, uczniowie - nie boją się mówić o tych latach jego życia, tak jak nie bał się tego ani nie usprawiedliwiał sam bohater sztambucha. Bogusława Sochańska, wieloletnia partnerka Jagiełły, pisze o jego stosunku do trudnego etapu kariery: „przyznał, że był w tym też element oportunizmu" (s. 164). W większości wspomnień powraca zatem temat jego działalności w partii, zwieńczonej objęciem wysokiego stanowiska, aż wreszcie — po wprowadzeniu stanu wojennego w 1981 r. — oddaniem partyjnej legitymacji. I choć z jednej strony autorzy uczciwie przyznają, że przynależność Jagiełły do PZPR była niezrozumiała i lekkomyślna, to z drugiej podkreślają, że wycofanie się z niej było niezwykłym aktem odwagi. Kulturoznawczyni Małgorzata Szpakowska wspomina też Jagiełłę przez pryzmat głośnego procesu taterników w 1970 r., w którym zeznawał on jako świadek powołany przez prokuraturę, bynajmniej nie na korzyść zasiadających na ławie oskarżonych. Okoliczności poznania Jagiełły, właśnie na owym procesie, nazywa więc „możliwie najgorszą sytuacją” (s. 179), ale konkluduje: „dziś, po prawie pięćdziesięciu latach, to wszystko i tak nie ma znaczenia" (s. 182).

Z kilku przynajmniej względów można Sztambuch nazwać książką odważną, bo zebrane w nim wspomnienia nie stronią od trudnych, nierzadko osobistych, 
czy wręcz intymnych tematów. Bynajmniej nie dotyczy to tylko polityki, ale także życia prywatnego Jagiełły. Bogusława Sochańska, opisując swój związek z Jagiełłą, wyznaje np., że żadne z nich nigdy nie zdecydowało się na rozwód $\mathrm{z}$ dotychczasowym małżonkiem. Autorka wspomnienia zastanawia się równocześnie, czy była to właściwa decyzja, ilustrując swą wypowiedź pięknymi, osobistymi wierszami Jagiełły: „osobno i razem / wolność z wyboru / i wybór z przeznaczenia" (s. 174).

Sztambuch Michała Jagiełty jest wyjątkową i piękną formą utrwalenia pamięci o tym niezwykłym człowieku, pisarzu i wielkim miłośniku gór. Jego różnorodność, bogactwo i wielość wspomnień w nim zawartych pokazują, że powracanie myślą do tych, którzy nas opuścili, może ubogacać — nie tylko najbliższych.

Anna Pigoń 